\title{
MJFA MMALSSANOONNA OF

\section{Determination of selected heavy metals in airborne particles in industrial area: A baseline study}

\author{
Azman Azid a,*, Siti Noor Syuhada Muhammad Amin b, Saiful Iskandar Khalit a, Salwani Ismail c, \\ Mohd Saiful Samsudin a, Ku Mohd Kalkausar Ku Yusof a, Nurul Latiffah Abd Rani a, Mohammad \\ Azizi Amran d, Kamaruzzaman Yunus e, Ahmad Shakir Mohd Saudi ${ }^{f}$
}

a Faculty Bioresources and Food Industry, Universiti Sultan Zainal Abidin, Besut Campus, 22200 Besut, Terengganu, Malaysia
o Faculty of Health Sciences, Universiti Sultan Zainal Abidin, Gong Badak Campus, 21300 Kuala Nerus, Terengganu, Malaysia
c Faculty of Medicine, Universiti Sultan Zainal Abidin, Medical Campus, Jalan Sultan Mahmud, 20400 Kuala Terengganu, Terengganu, Malaysia
a East Coast Environmental Research Institute, Universiti Sultan Zainal Abidin, Gong Badak Campus, 21300 Kuala Nerus, Terengganu, Malaysia
e Kulliyyah of Science, International Islamic University Malaysia, 25200 Kuantan, Pahang, Malaysia
f Institute of Medical Science and Technology, University of Kuala Lumpur, 43600 Kajang, Selangor, Malaysia

*Corresponding author: azmanazid@unisza.edu.my

\section{Article history}

Submitted 29 October 2017

Revised 14 January 2018

Accepted 11 February 2018

Published Online 4 June 2018

\begin{abstract}
This study focuses on airborne heavy metal pollution in the industrial area. Eight points from Paka and Gebeng Industrial Area respectively were selected for this study within two monsoon seasons. The samples were analysed for heavy metals ( $\mathrm{Cd}, \mathrm{As}, \mathrm{Cu}, \mathrm{Fe}, \mathrm{Ni}, \mathrm{Pb}$, and $\mathrm{Zn}$ ) by using inductively coupled plasma mass spectrometry (ICP-MS). The results showed that the mean concentration value of $\mathrm{As}, \mathrm{Pb}$ and $\mathrm{Cd}$ for Paka were $0.005 \mathrm{mg} / \mathrm{L} \pm 0.001,0.107 \mathrm{mg} / \mathrm{L} \pm 0.088$, and $0.010 \mathrm{mg} / \mathrm{L} \pm$ 0.008 , respectively and Gebeng were $0.004 \mathrm{mg} / \mathrm{L} \pm 0.002,0.069 \mathrm{mg} / \mathrm{L} \pm 0.059$ and $0.005 \mathrm{mg} / \mathrm{L} \pm$ 0.004 , respectively in the southwest monsoon - much higher than the target value by European Commission in Directive 2004/107/EC and Directive 2008/50/EC. It could be concluded that the industrial and transportation emission were the major source of heavy metals in the atmosphere along the Paka and Gebeng Industrial Area.
\end{abstract}

Keywords: Airborne pollution, heavy metal pollution, industrial area, ICP-MS, industrial emission

\section{INTRODUCTION}

Atmospheric particles constitute one of the major problems in the industrial areas. This particles generated by a variety of chemical species, ranging from metal to organic and inorganic compounds (Tsai \& Cheng 2004; Park \& Kim 2005). Atmospheric particles are involved in many processes at the atmosphere, and play an important role in visibility reduction, acid deposition and radiation balance, both directly and indirectly through the formation of clouds (Mészáros 1999; Kwak et al. 2012). Trace metals are natural constituents of the earth's crust, which is stable and cannot be degraded or destroyed. Heavy metals in the atmosphere may come from anthropogenic sources such as metal mining, fossil fuel combustion, metallurgical processing, incineration activities, industrial plants, and windblown dust (Kampa \& Castanas 2008; Hassanien 2009; Adeni et al. 2015).

Some heavy metals are toxic, can be present in the air, water and soil, which have all caused major human health problems in various parts of the world. The European Commission in Directive 2004/107/EC has set the target values for arsenic (As), nickel (Ni) and cadmium $(\mathrm{Cd})$ with the values of $0.006 \mathrm{e}-6,0.2 \mathrm{e}-6$ and $0.005 \mathrm{e}-6 \mathrm{mg} / \mathrm{L}$, respectively, and a limit value of $0.5 \mathrm{e}-6 \mathrm{mg} / \mathrm{L}$ for lead $(\mathrm{Pb})$ in Directive 2008/50/EC (Adani et al. 2015). Previous studies have shown that human exposure to high concentrations of heavy metals leads to their accumulation in the human body (Lee et al. 2006; Gbadebo \& Bankole 2007; Ripin et al. 2014). There are three routes of heavy metal exposure to human, via inhalation, ingestion and skin absorption. Health effect associated with trace metals in atmospheric particles will damage on all the cells of the body especially in respiratory, cardiovascular problems, premature mortality and etc. (Preiditis \& Adamson 2002; Magas et al. 2007; Callen et al. 2009; Wild et al. 2009; Lippmann 2009).

Determination of heavy metals content and their sources from atmospheric dust samples is a great important for strategic planning, quality management and proper pollution mitigation strategies. Information about the quality of atmospheric dust in Paka and Gebeng Industrial Area, Malaysia is still not monitored previously by other researchers. This study focuses on the concentrations of $\mathrm{As}, \mathrm{Ni}, \mathrm{Fe}, \mathrm{Cu}$, $\mathrm{Pb}, \mathrm{Cd}$ and $\mathrm{Zn}$ in atmospheric dust of Paka and Gebeng Industrial Area, Malaysia. These heavy metals have been selected for this study as the emission of the trafic and industrial activities can produce these heavy metals into the atmosphere and directly affect the human helath (Aksu 2015).The objectives of this study are (1) to determine the seasonal and spatial variability of the concentration of selected atmospheric dust of heavy metals; and (2) to identify the sources of heavy metals in the atmospheric dust around the study area.

\section{EXPERIMENTAL}

\section{Study area}

Sixteen (16) different points has been chosen (Table 1 and Fig. 1) for sampling purposes during two monsoon season, southwest (August and September 2016) and northeast (December 2016 and February 2017). The selection of the sampling site was based on several factors such as ease of access, safety, minimizing potential for sample contamination and representativeness. The description of sampling locations is given below. 
Table 1 Air monitoring and sampling location in Paka/Kerteh and Gebeng area.

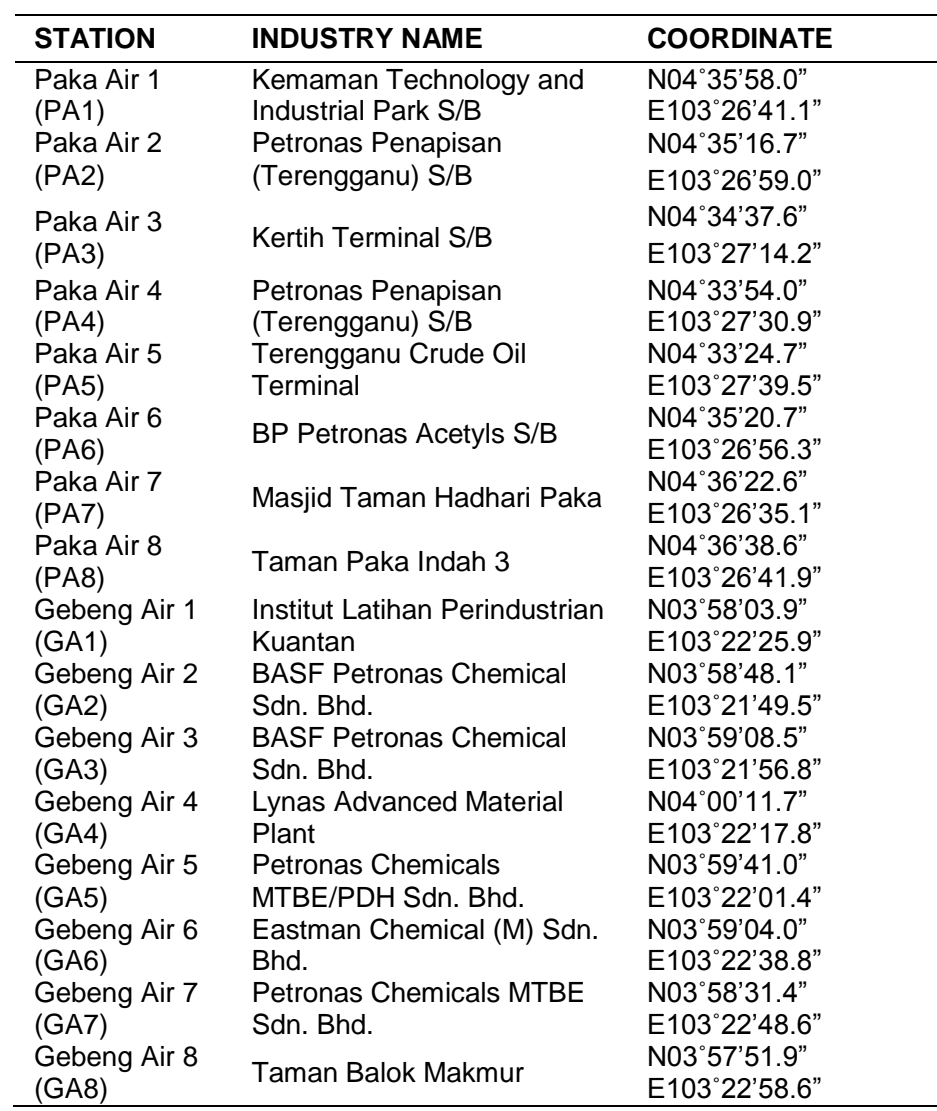

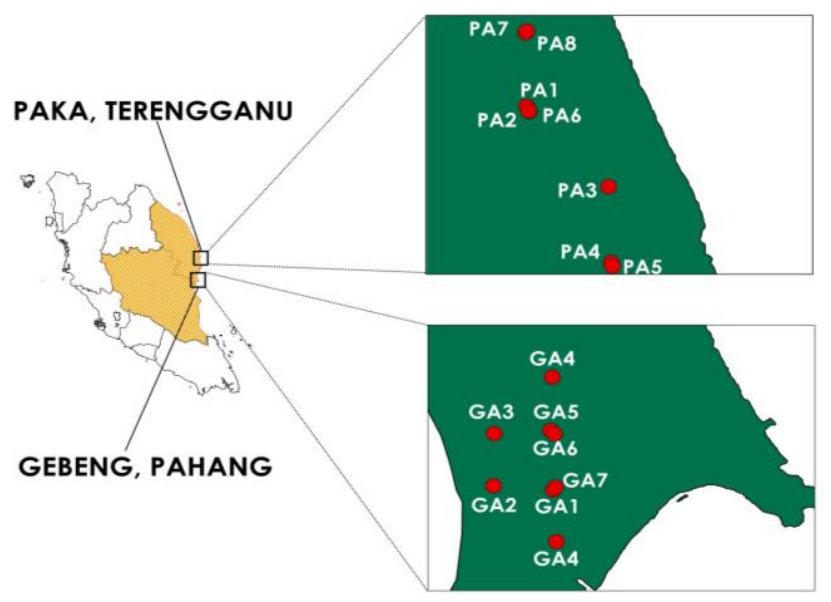

Fig. 1 Map of air sampling location in Paka/Kerteh and Gebeng Area.

The Gebeng Industrial Area (GIA) which is located in Pahang, Malaysia is a centre of chemical and petrochemical industries. GIA is a world-class petrochemical zone covers an area of 8,600 hectares, of which its strategic location with only 5 kilometres from Kuantan Port for the transfer of industrial production worldwide. GIA was managed and developed by District of Kuantan, Pahang authority. This industrial area provides a comprehensive chemical and petrochemical manufacturing facility including electricity, water, natural gas utility, telecommunication, fire fighting facilities and roads and railways for investors. Eight sampling locations around GIA have been selected to be monitored. This study location was selected due to the location of the most petrochemical activities that may contribute the growing of air pollution and health risk around this area.

Paka is a coastal town facing the South China Sea under District of Dungun authority (District area: $2,736 \mathrm{~km}^{2}$ ) in the state of Terengganu, Malaysia. The estimated population in Paka area is about 10,599 peoples. Oil and gas industries and activities were the main factors the immigrants from outside area enter into the Paka area.
Kerteh is a mukim in Kemaman District, Terengganu, Malaysia. The estimated population is about 3,064 peoples. Kerteh is an operations base for Petronas Chemicals Group Berhad, which oversees the oil platform operations off the state's coast as well as petrochemicals production and crude oil refining nearby Paka. The selection of this area is due to the location of the most energy sector, oil and gas activities produce the increasing of air pollution and health risk around this area. There are eight sampling locations along the main road of Paka and Kerteh area facing into the industrial zone.

\section{Meteorology of the sampling location}

Features climate of Malaysia are uniform temperature, high humidity and abundant rainfall. Winds are generally light. Weather in the study area is characterized by two monsoon regimes, namely the southwest monsoon which starts from late May to September, and the northeast monsoon from November to Mac. The prevailing wind in the southwest monsoon season is at a speed of light, below 15 knots. During northeast monsoon season, the prevailing winds are from the east or northeast at a speed of between 10 and 20 knots. The northeast monsoon brings heavy rain while the southwest monsoon showed relatively drier weather. The transition period between the two monsoons is known as transition periods.

\section{Sample collection}

The sampling was carried out in 2-days per each industrial area for a period of 7-months, started from August 2016 to February 2017. Each area consists of eight points. Each point, the process of sampling is 8hours. Air sampling was carried out using filter paper (Whatman ${ }^{\mathrm{TM}}$ No. $42, \leq 0.007 \%$ ash, pore size $2.5 \mu \mathrm{m}, 150 \mathrm{~mm}$ diameter), placed in air sampler (MAS-100 Eco Air Sampler) for particulate matter at a flow rate of $100 \mathrm{~L} / \mathrm{min}$ through an inlet designed to have $100 \%$ collection efficiency. Due to the hygroscopic nature of the filter paper, which results in the change of weight as a function of humidity, filter papers were carefully equilibrated for $48 \mathrm{~h}$ in a desiccator with a new silica gel, both before and after sampling, to eliminate the effect of humidity and also to obtain accurate particulate measurement. Only concentrations of particulate matter with the size $>2.5 \mu \mathrm{m}$ of collected over the filter paper were found. Air sampler was placed on an elevated platform of $1.5 \mathrm{~m}$ due to this high be sufficient to human breath level. After sampling, the loaded filters were removed from the air sampler and placed in cleaned plastic bag and protected from light as well as dried in a desiccator for $48 \mathrm{~h}$. The mass of the aerosol particles collected on each filter paper was determined by the difference in weights before and after sampling, using an electronic micro-balance (Sartorius ${ }^{\mathrm{TM}}$ SECURA225D1SPR) with $0.01 \mathrm{mg}$ precision.

\section{Sample digestion}

For precise analysis, analytical grade reagents were used in this study. 5\% concentrated nitric acid $\left(\mathrm{HNO}_{3}\right.$, ACS Reagent, $70 \%$, SigmaAldrich) was used as a pre-cleaned reagent for all laboratory apparatuses and glassware and rinsed with deionized water. The samples and heavy metal content for air particulate in the certified standard reference materials (NIST ${ }^{\circledR}$ SRM $^{\circledR}$ 1648a) were digested for elemental analysis. The $\mathrm{SRM}^{\circledR} 1648 \mathrm{a}$ standard (urban particulate matter) was used for checking the quality and accuracy of quantitative analysis. Digestion samples were conducted using the aqua regia method as described by Radojevic \& Bashkin (2006). Aqua regia method is a process of mixture of nitric acid and hydrochloric acid, optimally in a molar ratio of $1: 3$, which is a digestion procedure that consider adequate for environmental samples (Vercoutere et al. 1995; Chen \& Ma 2001). Aqua regia digestion is widely used for determination of the contents of heavy metal elements to solve environmental tasks (Soon \& Abboud 1993; Taraškevičius et al. 2013).

Whatman ${ }^{\mathrm{TM}}$ filter papers (blank and samples) that have been cut into small pieces and SRM ${ }^{\circledR}$ 1648a were placed into a $100 \mathrm{~mL}$ beaker (separate beaker, respectively) and treated with $50 \mathrm{~mL}$ of aqua regia. The beakers were covered with watch glass during heating process. The mixture was heated at $140{ }^{\circ} \mathrm{C}$ to near dryness. The samples were filtered off while the beaker rinsed with $10 \% \mathrm{HNO}_{3}$. These processes were repeated for three times. Then, the solutions were cooled at room temperature, transferred into a $100 \mathrm{~mL}$ volumetric flask and diluted to 
volume with $10 \% \mathrm{HNO}_{3}$ for final solution. Triplicate samples were prepared and tested for reliability, accuracy and precise of finding. Blanks and a series of standard solutions were prepared. A series of standard solutions were prepared from stock standard solutions (ICP Multi-element standard solution IV, Merck) that were diluted with ultra-pure water. The solutions were subjected immediately for trace elemental determination by ICP-MS. The SRM ${ }^{\circledR} 1648$ a recoveries of ions and elements were in the range of $80 \%-110 \%$ (Table 2).

Table 2 Recovery of metal using certified reference materials $\left(\mathrm{NIST}^{\oplus} \mathrm{SRM}^{\circledR} 1648 \mathrm{a}\right.$ ) of urban particulate matter

\begin{tabular}{cccc}
\hline Metals & $\begin{array}{c}\text { Certified Value } \\
(\mathbf{p p m})\end{array}$ & $\begin{array}{c}\text { Measured } \\
\text { Value }(\mathbf{p p m})\end{array}$ & Recovery (\%) \\
\hline $\mathrm{Fe}$ & $0.0392 \pm 0.0021$ & $0.0396 \pm 0.0008$ & 101.0 \\
$\mathrm{Ni}$ & $81.1 \pm 6.8$ & $79.8 \pm 6.1$ & 98.4 \\
$\mathrm{Cu}$ & $610.0 \pm 70$ & $601.8 \pm 67$ & 98.7 \\
$\mathrm{~Pb}$ & $0.0066 \pm 0.0003$ & $0.0059 \pm 0.0001$ & 89.4 \\
$\mathrm{Cd}$ & $73.7 \pm 2.3$ & $72.8 \pm 1.6$ & 98.8 \\
$\mathrm{As}$ & $115.5 \pm 3.9$ & $114.3 \pm 3.7$ & 99.0 \\
$\mathrm{Zn}$ & $4800 \pm 270$ & $4789 \pm 272$ & 99.8 \\
\hline
\end{tabular}

\section{Analytical instrumentation}

ICP-MS (Model ELAN DRC-e, Perkin Elmer, Shelton, CT) has been used to carry out the elemental analysis. ICP-MS was selected for analysis of heavy metals because of its selectivity, sensitivity, reproducibility, wide dynamic concentration range, and its low cost (Thomas 2008). ICP-MS is a powerful technique allowing the multielemental ultra-trace analysis of a wide variety of samples (Beauchemin 2006).

Prior to analysis, daily performance check of ICP-MS was undertaken and a new quantitative analysis method was created. The elements ( $\mathrm{As}, \mathrm{Ni}, \mathrm{Fe}, \mathrm{Cu}, \mathrm{Pb}, \mathrm{Cd}$ and $\mathrm{Zn}$ ) that would be measured were selected and other related fields were populated automatically. This method has been stored in the instrument. Each element has been calibrated and recorded in the instrument using the blank solution (ultra-pure water) and stock solutions. After calibration, all samples were analysed and the data was recorded.

\section{Statistical analysis}

The descriptive statistic was conducted to describe the main characteristic of heavy metal in Paka and Gebeng Industrial Area's atmosphere for southwest monsoon and northeast monsoon along the study area. The descriptive statistic comprises analyses such as mean, minimum, maximum and standard deviation. Analysis of variance (ANOVA) test was used to test the significant difference of all heavy metals among sampling stations.

Principal component analysis (PCA) was used to identify atmospheric pollution sources contributing the heavy metals along the study area by 'removing' the less significant parameters with minimum loss of important original information (Ismail et al. 2016; Azid et al. 2017). In this study, PCA was chosen as a statistical tool because it has the ability to show the most significant variables that can contributed in the study area, which it also can indicate the source of the pollutants (Azid et al. 2014). Theoritically, PCA creates latent variables (scores) which are the linear combinations of the original data variables of the heavy metal concentrations. In PC analyses for heavy metals, latent variables with eigenvalue $>1.0$ are considered significant. Data were statistically calculated and analyzed using the XLSTAT version 2014. PCA can be expressed based on the following equation:

$$
z_{i j}=a_{i 1} x_{1 j}+a_{i 2} x_{2 j}+a_{i 3} x_{3 j}+a_{i m} x_{m j}
$$

where, $z$ is the component score, $a$ is a component loading, $x$ is the measured heavy metal variables, $i$ is the component number and $m$ is the total of heavy metal variables. PCA will produce the list of variables that are dominant from less significant until the most significant variables that influence positive maximum and negative minimum peak of the spatial variation pattern.

\section{RESULTS AND DISCUSSION}

\section{Descriptive analysis}

Mean value of each parameter were used to investigate the behaviour of heavy metals in air. ANOVA test on the samples showed that the heavy metals studied have significant different $(\mathrm{p}<0.05)$ between the sampling stations. Table 3 and Figure 2 show the descriptive statistics of heavy metal concentrations in Paka and Gebeng Industrial Area air. The total heavy metal concentrations were found to be in the order of $\mathrm{Fe}>\mathrm{Pb}>\mathrm{Zn}>\mathrm{Cd}>\mathrm{As}>\mathrm{Cu}>\mathrm{Ni}$ for Paka Industrial Area (southwest monsoon and northeast monsoon, respectively), whereas $\mathrm{Fe}>\mathrm{Zn}>\mathrm{Pb}>\mathrm{Cu}>\mathrm{Cd}>\mathrm{As}>\mathrm{Ni}$ (Southwest Monsoon and Northeast Monsoon) for Gebeng Industrial Area.

Table 3 Descriptive information for (a) Paka (Southwest Monsoon), (b) Paka (Northeast Monsoon), (c) Gebeng (Southwest Monsoon), and (d) Gebeng (Northeast Monsoon).

\begin{tabular}{|c|c|c|c|c|c|c|c|}
\hline Statistic & $\begin{array}{c}\mathrm{Fe} \\
(\mathrm{mg} / \mathrm{L})\end{array}$ & $\begin{array}{c}\mathrm{Ni} \\
(\mathrm{mg} / \mathrm{L})\end{array}$ & $\begin{array}{c}\mathrm{Cu} \\
(\mathrm{mg} / \mathrm{L})\end{array}$ & $\begin{array}{c}\mathrm{Pb} \\
(\mathrm{mg} / \mathrm{L})\end{array}$ & $\begin{array}{c}\mathrm{Cd} \\
(\mathrm{mg} / \mathrm{L})\end{array}$ & $\begin{array}{c}\mathrm{As} \\
(\mathrm{mg} / \mathrm{L})\end{array}$ & $\begin{array}{c}\mathrm{Zn} \\
(\mathrm{mg} / \mathrm{L})\end{array}$ \\
\hline Minimum & 0.129 & $\mathrm{~N} / \mathrm{D}$ & 0.001 & 0.004 & 0.001 & 0.003 & 0.010 \\
\hline Maximum & 0.473 & N/D & 0.006 & 0.463 & 0.031 & 0.006 & 0.348 \\
\hline Mean & 0.272 & N/D & 0.002 & 0.107 & 0.010 & 0.005 & 0.104 \\
\hline$S D(n-1)$ & 0.103 & $\mathrm{~N} / \mathrm{D}$ & 0.001 & 0.088 & 0.008 & 0.001 & 0.072 \\
\hline $\begin{array}{l}\text { Directive } \\
2004 / 107 / E C\end{array}$ & & $0.2 \mathrm{e}-6$ & & & $0.005 e-6$ & $0.006 e-6$ & \\
\hline $\begin{array}{l}\text { Directive } \\
\text { 2008/50/EC }\end{array}$ & & & & $0.5 e-6$ & & & \\
\hline
\end{tabular}

(b)

\begin{tabular}{lccccccc}
\hline Statistic & $\begin{array}{c}\mathbf{F e} \\
(\mathbf{m g} / \mathbf{L})\end{array}$ & $\begin{array}{c}\mathbf{N i} \\
(\mathbf{m g} / \mathbf{L})\end{array}$ & $\begin{array}{c}\mathbf{C u} \\
(\mathbf{m g} / \mathbf{L})\end{array}$ & $\begin{array}{c}\mathbf{P b} \\
(\mathbf{m g} / \mathbf{L})\end{array}$ & $\begin{array}{c}\mathbf{C d} \\
(\mathbf{m g} / \mathbf{L})\end{array}$ & $\begin{array}{c}\text { As } \\
(\mathbf{m g} / \mathbf{L})\end{array}$ & $\begin{array}{c}\mathbf{Z n} \\
(\mathbf{m g} / \mathbf{L})\end{array}$ \\
\hline Minimum & 0.087 & $\mathrm{~N} / \mathrm{D}$ & 0.000 & 0.003 & 0.001 & 0.000 & 0.000 \\
Maximum & 0.200 & $\mathrm{~N} / \mathrm{D}$ & 0.004 & 0.444 & 0.012 & 0.005 & 0.183 \\
Mean & 0.125 & $\mathrm{~N} / \mathrm{D}$ & 0.002 & 0.107 & 0.005 & 0.002 & 0.052 \\
SD $(\mathrm{n}-1)$ & 0.041 & $\mathrm{~N} / \mathrm{D}$ & 0.001 & 0.098 & 0.004 & 0.001 & 0.44 \\
\hline $\begin{array}{l}\text { Directive } \\
\text { 2004/107/EC }\end{array}$ & & $0.2 \mathrm{e}-6$ & & & $0.005 \mathrm{e}-6$ & $0.006 \mathrm{e}-6$ & \\
\hline Directive & & & & $0.5 \mathrm{e}-6$ & & & \\
2008/50/EC & & & & & & &
\end{tabular}




\begin{tabular}{|c|c|c|c|c|c|c|c|}
\hline Statistic & $\begin{array}{c}\mathrm{Fe} \\
(\mathrm{mg} / \mathrm{L})\end{array}$ & $\begin{array}{c}\mathrm{Ni} \\
(\mathrm{mg} / \mathrm{L})\end{array}$ & $\begin{array}{c}\mathrm{Cu} \\
(\mathrm{mg} / \mathrm{L})\end{array}$ & $\begin{array}{c}\mathrm{Pb} \\
(\mathrm{mg} / \mathrm{L})\end{array}$ & $\begin{array}{c}\mathrm{Cd} \\
(\mathrm{mg} / \mathrm{L})\end{array}$ & $\begin{array}{c}\mathrm{As} \\
(\mathrm{mg} / \mathrm{L})\end{array}$ & $\begin{array}{c}\mathrm{Zn} \\
(\mathrm{mg} / \mathrm{L})\end{array}$ \\
\hline Minimum & 0.206 & $N / D$ & 0.001 & 0.004 & 0.001 & 0.001 & 0.053 \\
\hline Maximum & 1.090 & N/D & 0.023 & 0.195 & 0.015 & 0.006 & 0.278 \\
\hline Mean & 0.542 & $N / D$ & 0.007 & 0.069 & 0.005 & 0.004 & 0.117 \\
\hline$S D(n-1)$ & 0.318 & N/D & 0.006 & 0.059 & 0.004 & 0.002 & 0.066 \\
\hline $\begin{array}{l}\text { Directive } \\
2004 / 107 / \text { EC }\end{array}$ & & $0.2 \mathrm{e}-6$ & & & $0.005 e-6$ & $0.006 e-6$ & \\
\hline $\begin{array}{l}\text { Directive } \\
\text { 2008/50/EC } \\
\end{array}$ & & & & $0.5 e-6$ & & & \\
\hline \\
\hline Statistic & $\begin{array}{c}\mathrm{Fe} \\
(\mathrm{mg} / \mathrm{L})\end{array}$ & $\begin{array}{c}\mathrm{Ni} \\
(\mathrm{mg} / \mathrm{L}) \\
\end{array}$ & $\begin{array}{c}\mathrm{Cu} \\
(\mathrm{mg} / \mathrm{L})\end{array}$ & $\begin{array}{c}\mathrm{Pb} \\
(\mathrm{mg} / \mathrm{L})\end{array}$ & $\begin{array}{c}\mathrm{Cd} \\
(\mathrm{mg} / \mathrm{L})\end{array}$ & $\begin{array}{c}\text { As } \\
\text { (mg/L) }\end{array}$ & $\begin{array}{c}\mathrm{Zn} \\
(\mathrm{mg} / \mathrm{L})\end{array}$ \\
\hline Minimum & 0.102 & $N / D$ & 0.000 & 0.002 & 0.000 & 0.000 & 0.050 \\
\hline Maximum & 0.757 & $N / D$ & 0.019 & 0.112 & 0.007 & 0.002 & 0.210 \\
\hline Mean & 0.311 & $\mathrm{~N} / \mathrm{D}$ & 0.006 & 0.051 & 0.003 & 0.001 & 0.113 \\
\hline$S D(n-1)$ & 0.237 & $N / D$ & 0.003 & 0.034 & 0.002 & 0.0004 & 0.056 \\
\hline $\begin{array}{l}\text { Directive } \\
\text { 2004/107/EC }\end{array}$ & & $0.2 \mathrm{e}-6$ & & & $0.005 e-6$ & $0.006 e-6$ & \\
\hline $\begin{array}{l}\text { Directive } \\
\text { 2008/50/EC }\end{array}$ & & & & $0.5 e-6$ & & & \\
\hline
\end{tabular}

The results showed that the highest heavy metal concentration in both areas were Fe. Based on the land use in both areas, the presence of $\mathrm{Fe}$ in atmosphere may come from Petrochemical industries and transportation activities, where the combustion of fossil fuels and biomass may burst during combustion (Wang et al. 2015).

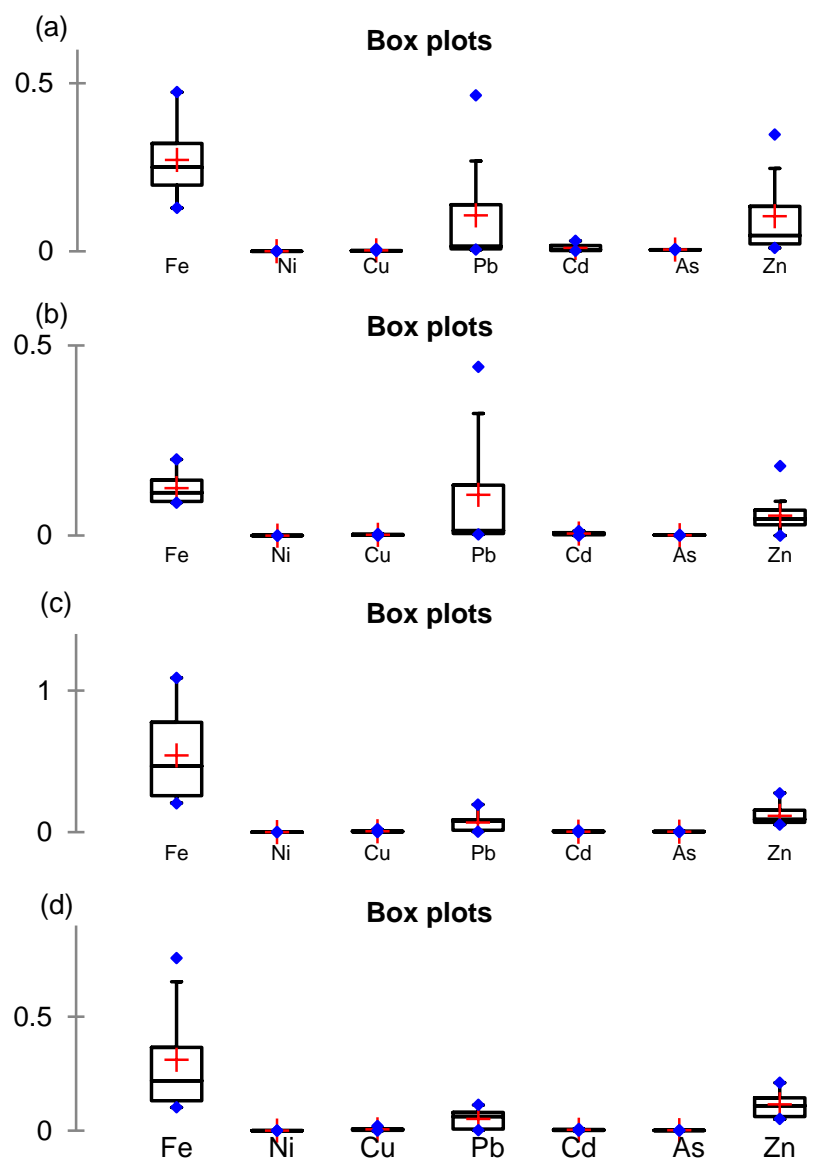

Fig. 2 Box plots for (a) Paka (Southwest Monsoon), (b) Paka (Northeast Monsoon), (c) Gebeng (Southwest Monsoon), and (d) Gebeng (Northeast Monsoon).
Based on Fig. 2, the highest concentration of Fe was detected in Gebeng Industrial Area with the value of $0.542 \mathrm{mg} / \mathrm{L} \pm 0.317$ compare to Paka Industrial Area $(0.272 \mathrm{mg} / \mathrm{L} \pm 0.103)$ in the southwest monsoon. The highest value of $\mathrm{Fe}$ for the northeast monsoon also showed that Gebeng Industrial Area contributes more than Paka Industrial Area with the value of $0.311 \mathrm{mg} / \mathrm{L} \pm 0.237$ and $0.125 \mathrm{mg} / \mathrm{L}$ \pm 0.041 , respectively. The highest concentration of $\mathrm{Zn}$ was detected in Gebeng Industrial Area compare to Paka Industrial Area in the southwest monsoon and northeast monsoon with the value of 0.117 $\mathrm{mg} / \mathrm{L} \pm 0.066,0.104 \mathrm{mg} / \mathrm{L} \pm 0.0724,0.114 \mathrm{mg} / \mathrm{L} \pm 0.056$ and 0.053 $\mathrm{mg} / \mathrm{L} \pm 0.044$, respectively. Meanwhile, the present of $\mathrm{Cu}$ in both monsoons in both areas were too low as well as no detection for $\mathrm{Ni}$. WHO (1996) mentioned that $\mathrm{Fe}, \mathrm{Zn}, \mathrm{Cu}$ and $\mathrm{Ni}$ are categorised as essential micro-nutrients, which are required for various biochemical and physiological functions. Insufficient supply of these metals may result in a variety of deficiency diseases or syndromes (WHO 1996; Tchounwou et al. 2014). However, too much exposure to $\mathrm{Cu}$ has been linked to cellular damage leading to Wilson disease in humans (ATSDR 2002; Tchounwou et al. 2008; Tchounwou et al. 2014).

Based on the finding, Paka Industrial Area released more on heavy metals such as $\mathrm{As}, \mathrm{Pb}$ and $\mathrm{Cd}$ in the atmosphere compare to Gebeng Industrial Area, neither in the southwest monsoon nor northeast monsoon. The results show that the mean value concentration of As, $\mathrm{Pb}$ and $\mathrm{Cd}$ in the Paka Industrial Area were $0.005 \mathrm{mg} / \mathrm{L} \pm 0.001,0.107$ $\mathrm{mg} / \mathrm{L} \pm 0.088$, and $0.010 \mathrm{mg} / \mathrm{L} \pm 0.008$, respectively for the southwest monsoon. For the northeast monsoon, Paka Industrial Area was released these heavy metals in the atmosphere with the mean concentration of $0.002 \mathrm{mg} / \mathrm{L} \pm 0.001,0.107 \mathrm{mg} / \mathrm{L} \pm 0.098$ and 0.005 $\mathrm{mg} / \mathrm{L} \pm 0.004$, respectively. Meanwhile, the mean concentration value of $\mathrm{As}, \mathrm{Pb}$ and $\mathrm{Cd}$ in Gebeng Industrial Area were $0.004 \mathrm{mg} / \mathrm{L} \pm 0.002$, $0.069 \mathrm{mg} / \mathrm{L} \pm 0.059$ and $0.005 \mathrm{mg} / \mathrm{L} \pm 0.004$, respectively (southwest monsoon). In the northeast monsoon, Gebeng Industrial Area released these heavy metals in the atmosphere with the mean concentration value of $0.001 \mathrm{mg} / \mathrm{L} \pm 0.0004,0.051 \mathrm{mg} / \mathrm{L} \pm 0.034$ and $0.003 \mathrm{mg} / \mathrm{L} \pm$ 0.002 , respectively. Several studies from Tchounwou et al. (2001), Tchounwou et al. (2004a), Tchounwou et al. (2004a), Tchounwou et al. (2004b), Yedjou \& Tchounwou (2006), Yedjou \& Tchounwou (2007) and Yedjou \& Tchounwou (2008) have demonstrated that the heavy metals of $\mathrm{As}, \mathrm{Cd}$ and $\mathrm{Pb}$ which react to reactive oxygen species (ROS) production and oxidative stress may play a key role in the toxicity and carcinogenicity to the public health. These metals may induce multiple organ damage, even at lower levels of exposure 
(Tchounwou et al. 2014). Based on this study, the mean concentration value of $\mathrm{As}, \mathrm{Pb}$ and $\mathrm{Cd}$ are much higher than the target value by European Commission in Directive 2004/107/EC and Directive 2008/50/EC.

\section{Principal component analysis (PCA)}

PCA was performed to dimensionality of data set reduction and to find out the sources of pollution that made some groups based on identical sources. Three principal components (PCs) for Paka and Gebeng Industrial Area respectively were extracted from PCA after rotation, which are based on eigenvalue more than 1 . Selected PCs contributed $86.939 \%$ and $76.444 \%$ of the total variation for Paka and Gebeng, respectively. Communality values for the selected PCs in Paka show highest value for the heavy metals of $\mathrm{Cu}, \mathrm{As}, \mathrm{Pb}, \mathrm{Fe}, \mathrm{Cd}, \mathrm{Zn}$ with the value of $95.4 \%, 88.6 \%, 86.9 \%, 84.6 \%, 83.4 \%$ and $82.7 \%$, respectively.

Communality values (Table 4) for the selected PCs in Gebeng can be divided into two, highest and moderate values. The highest values of communality in Gebeng were $\mathrm{Cd}(91.2 \%), \mathrm{Pb}(86.8 \%)$ and $\mathrm{Fe}$ $(86.2 \%)$. The moderate values of communality in Gebeng were $\mathrm{Zn}$ (73.9), $\mathrm{Cu}(69.6 \%$ and As $(50.9 \%)$. Purposely, the individual communalities would like to tell how well the performance assessment of PCA model is working for the individual variables. Then, these results further confirm the choice of the selected number of PCs.

The loadings from PCA (Table 4) are based on the three rotated PCs (RPCs) for Paka and Gebeng Industrial Area. Only the moderate $(0.50-0.75)$ and highest $(>0.75)$ correlations between variables are noted in bold. In Paka Industrial Area, RPC 1 was strongly loaded with $\mathrm{Pb}, \mathrm{Cd}$ and $\mathrm{Zn}$ which show highest positive correlation among them. RPC 2 illustrated highest loading for As and Fe. The only meaningful loading in RPC 3 was $\mathrm{Cu}$. In the Gebeng Industrial Area, RPC 1 shows highest loaded on $\mathrm{Pb}$ and $\mathrm{Cd}$. In case of $\mathrm{RPC} 2, \mathrm{Cu}$ and As were identify as moderate loading, while the highest loading was $\mathrm{Zn}$. Meanwhile, only Fe was loaded in RPC 3.

Table 4 Varifactors after varimax rotation (Extraction Method: PCA) and the possible source category in the study area for: (a) Paka Industrial Area and (b) Gebeng Industrial Area.

(a)

\begin{tabular}{lcccc}
\hline \multirow{2}{*}{ Parameter } & \multicolumn{3}{c}{ Component } & \multirow{2}{*}{ Communality } \\
\cline { 2 - 4 } & RPC 1 & RPC 2 & RPC 3 & \\
\hline $\mathrm{Fe}$ & 0.446 & $\mathbf{0 . 8 0 3}$ & 0.055 & 0.846 \\
$\mathrm{Cu}$ & 0.052 & 0.045 & $\mathbf{0 . 9 7 5}$ & 0.954 \\
$\mathrm{~Pb}$ & $\mathbf{0 . 8 5 7}$ & -0.100 & 0.353 & 0.869 \\
$\mathrm{Cd}$ & $\mathbf{0 . 8 7 2}$ & 0.253 & 0.097 & 0.834 \\
$\mathrm{As}$ & -0.055 & $\mathbf{0 . 9 4 0}$ & -0.003 & 0.886 \\
$\mathrm{Zn}$ & $\mathbf{0 . 8 4 6}$ & 0.165 & -0.290 & 0.827 \\
\hline Eigenvalue & 2.752 & 1.350 & 1.115 & \\
\% of variance & 45.867 & 22.496 & 18.577 & \\
\% cum. of variance & 45.867 & 68.363 & 86.939 & \\
\hline
\end{tabular}

(b)

\begin{tabular}{lcccc}
\hline \multirow{2}{*}{ Parameter } & \multicolumn{3}{c}{ Component } & \multirow{2}{*}{ Communality } \\
\cline { 2 - 4 } & RPC 1 & RPC 2 & RPC 3 & \\
\hline $\mathrm{Fe}$ & 0.060 & 0.105 & $\mathbf{0 . 9 2 1}$ & 0.862 \\
$\mathrm{Cu}$ & -0.056 & $\mathbf{0 . 5 6 0}$ & -0.616 & 0.696 \\
$\mathrm{~Pb}$ & $\mathbf{0 . 9 1 6}$ & -0.096 & 0.139 & 0.868 \\
$\mathrm{Cd}$ & $\mathbf{0 . 9 5 5}$ & 0.010 & -0.012 & 0.912 \\
$\mathrm{As}$ & 0.400 & $\mathbf{0 . 5 9 1}$ & -0.014 & 0.509 \\
$\mathrm{Zn}$ & -0.278 & $\mathbf{0 . 8 1 2}$ & 0.044 & 0.739 \\
\hline Eigenvalue & 2.0714 & 1.4679 & 1.0474 & \\
\% of variance & 34.524 & 24.465 & 17.456 & \\
\% cum. of variance & 34.524 & 58.988 & 76.444 & \\
\hline
\end{tabular}

Three factors were grouped separately for Paka and Gebeng Industrial Area. In Paka area, Factor 1 contributes $\mathrm{Pb}, \mathrm{Cd}$ and $\mathrm{Zn}$. These components probably originated from the coal burning in power station plant which located in that area. According to Smołka-Danielowska (2006), $\mathrm{Pb}, \mathrm{Cd}$ and $\mathrm{Zn}$ play the role of heavy metal contributors in the power station plant. These metals also may come from petroleum combustion in the refinery crude oil plant, petrochemicals and transportation activities in Paka Industrial area. Akhter \& Madany (1993) and Madany et al. (1994, 1996) in Freije (2015) found that petroleum hydrocarbon from petroleum plant and fuel combustion from transportations were contributors to $\mathrm{Pb}, \mathrm{Cd}$ and $\mathrm{Zn}$. Factor 2 contributes $\mathrm{Fe}$ and As. As may come from several arsenic-containing compounds that have been used to manufacture products with agricultural applications such as insecticides, herbicides, fungicides, algaecides, sheep dips, wood preservatives, and dye-stuffs (Tchounwou et al. 2014). Fe may come from industrial sources include metal processing in refineries and smelting operation (Tchounwou et al. 2014). Factor 3 only contributes $\mathrm{Cu}$. The presence of $\mathrm{Cu}$ in the Paka Industrial Area's air may come from building construction and power generation and transmission activities.

In Gebeng area, Factor 1 contributes $\mathrm{Pb}$ and $\mathrm{Cd}$, Factor 2 contributes $\mathrm{Cu}, \mathrm{As}$ and $\mathrm{Zn}$ and Factor 3 contributes Fe. Based on the land use activities in the Gebeng Industrial Area, it is confirmed that these metals may come from the mining, foundries and smelters, petrochemicals, plastics, microelectronic, wood preservation, power stations and other metal-based industrial operations (Pacyna et al. 1996; Arruti et al. 2010; Sträter et al. 2010).

\section{CONCLUSION}

The detected levels of $\mathrm{As}, \mathrm{Cd}, \mathrm{Zn}$, and $\mathrm{Pb}$ in the study area were much higher than the target value by European Commission in Directive 2004/107/EC and Directive 2008/50/EC. Studies on health risks to workers and residents in the study area should be held as the mean concentration values of these heavy metals exceed the values set by international standards. Despite the metals concentration value of air in Malaysia has not yet set up, but the impending need to fully investigate and assess the suitability of the other industrial development in these areas can be governed. This study also has revealed that the metals sources along the Paka and Gebeng Industrial Area are originated from industrial and transportation activities. Moreover, air samples collected for metals analyses were successfully describe the magnitude of heavy metals pollution in the atmospheric system. This profiling will be useful for future comparative metals pollution studies and monitoring works on the land bases and air pollution inputs especially in the other international air-ways. Furthermore, the metals information from this study will help the relevant authorities in reviewing current regulations and imposes more stringent standards on pollutants emission into atmospheric system. Future monitoring work should also include physico-chemicals information for better air quality analyses. These approaches will provide a better insight into air quality information to understand potential environmental health hazard.

\section{ACKNOWLEDGEMENT}

We gratefully acknowledge the Chemistry Department, Kulliyyah of Science, International Islamic University Malaysia for providing the required research facilities for this work. We are also thankful to the reviewers of this paper for reviewing the paper and providing their valuable suggestions. We would also like to acknowledge Universiti Sultan Zainal Abidin for providing the financial support through grant UniSZA/2016/DPU/01 to carry out this work.

\section{REFERENCES}

Adani, M., Mircea, M., D’Isidoro, M., Costa, M. P. \& Silibello, C. 2015. Heavy metal modelling study over Italy: effects of grid resolution, lateral 
boundary conditions and foreign emissions on air concentrations. Water Air Soil Pollut. 226: 46. doi: 10.1007/s11270-015-2324-7.

Agency for Toxic Substances and Disease Registry (ATSDR). 2002 Toxicological profile for copper. Atlanta, GA: Centers for Disease Control.

Akhter, M. S. \& Madany, I. S. 1993. Heavy metals in street and house dust in Bahrain. Water Air Soil Pollut. 66: 111-119.

Aksu, A. 2015. Source of metal pollution in the urban atmosphere (A case study: Tuzla, Istabul). J. Environ. Health Sci. Eng. 13: 79.

Arruti, A., Fernández-Olmo, I. \& Irabien, A. 2010. Evaluation of the contribution of local sources to trace metals levels in urban PM2.5 and PM10 in the Cantabria region (Northern Spain). J. Environ. Monit. 12 (7): $1451-1458$.

Azid, A., Rani, N. A. A., Samsudin, M. S., Khalit, S. I., Gasim, M. B. Kamarudin, M. K. A., Yunus, K., Saudi, A. S. M. \& Yusof, K. M. K. K. 2017. Air quality modelling using chemometric techniques. J Fundam Appl Sci. 9 (2S): 443 - 466.

Azid, A., Juahir, H., Toriman, M. E., Kamarudin, M. K. A., Saudi, A. S. M., Hasnam, C. N. C., Aziz, N. A. A., Azaman, F., Latif, M. T., Zainuddin, S. F. M., Osman, M. R. \& Yamin, M. 2014. Prediction of the level of air pollution using principal component analysis and artificial neural network techniques: a case study in Malaysia. Water Air Soil Pollut. 225: 2063. doi: 10.1007/s11270-014-2063-1

Beauchemin, D. 2006. Inductively coupled plasma mass spectrometry. Anal. Chem. 78: 4111-4136.

Callen, M. S., de la Cruz, M. T., Lopez, J. M., Navarro, M. V. \& Mastral, A. M. 2009. Comparison of receptor models for source apportionment of the PM10 in Zaragoza (Spain). Chemosphere. 76: 1120-1129.

Freije, A.M. 2015. Heavy metal, trace element and petroleum hydrocarbon pollution in the Arabian Gulf: Review. J Assoc of Arab Uni for Basic and Appl Sci. 17: 90-100.

Gbadebo, A.M. \& Bankole, O.D. 2007. Analysis of potententially toxic metals in airborne cement dust around Sagamu South Western Nigeria. J Appl Sci. 7: $35-40$.

Hassanien, M.A. 2009. Atmospheric heavy metals pollution: Exposure and prevention policies in Mediterranean basin. In: L. I. Simeonov et al. (eds.), Environmental heavy metal pollution and effects on child mental development: risk assessment and prevention strategies Pp. 287-307.

Ismail, A., Toriman, M.E., Juahir, H., Zain, S.M., Habir, N.L.A., Retnam, A., Kamarudin, M.K.A., Umar, R. \& Azid, A. 2016. Spatial assessment and source identification of heavy metals pollution in surface water using several chemometric techniques. Mar Poll Bull. 106: 292-300.

Kampa, M. \& Castanas, E. 2008. Human health effects of air pollution. Environ Poll. 151: 362-367.

Kwak, J-H., Kim, G., Kim,Y-J \& Park, K. 2012. Determination of Heavy Metal Distribution in PM10 During Asian Dust and Local Pollution Events Using Laser Induced Breakdown Spectroscopy (LIBS). Aerosol Sci Techn. 46: 1079-1089.

Lee, C.S., Li, X., Shi, W., Cheung, S.C. \& Thornton, I. (2006). Metal contamination in urban, suburban, and country park soils of Hong Kong: A study based on GIS and multivariate statistics. Sci Tot Environ. 356: 4561.

Lippmann, M. 2009. Environmental Toxicants: Human Exposures and Their Health Effects, Third Edition. John Wiley \& Sons, Inc, Hobokan, NJ.

Madany, I.M., Akhter, M.S. \& Al Jowder, O.A. 1994. The correlations between heavy metals in residential indoor dust and outdoor street dust in Bahrain. Environ. Inter. 20 (4): 483-492.

Madany, I.M., Al-Aawi, Z. \& Abdul Wahab, A. 1996. Trace metal concentrations in marine organisms from the coastal area of Bahrain. Water Air Soil Pollut. 91: 233-248.
Magas, O. K., Gunter, J. T. \& Regens, J. L. 2007. Ambient Air Pollution and Daily Pediatric Hospitalizations for Asthma. Environ Sci Poll Res. 14: 1923. Doi: $10.1065 / \mathrm{espr} 2006.08 .333$

Mészáros, E. 1999. Fundamentals of atmospheric aerosol chemistry. Budapest: Akadémiai Kiadó.

Pacyna, J. M. 1996. Monitoring and assessment of metal contaminants in the air. In: Chang, L. W., Magos, L., Suzuli, T. (Eds.) Toxicology of metals. Boca Raton, FL: CRC Press, p. 9-28.

Park, S. S. \& Kim, Y. J. 2005. Source Contributions to Fine Particulate Matter in an Urban Atmosphere. Chemosphere 59: 217-226

Prieditis, H. \& Adamson, I.Y.R. 2002. Comparative pulmonary toxicity of various soluble metals found in urban particulate dusts. Exp. Lung Res. 28: 563-576.

Radojevic, M. \& Bashkin, V. N. 2006. Practical environmental analysis. London, UK: Royal Society of Chemistry.

Ripin, S.N.M., Hasan, S., Kamal, M.L. \& Hashim, N.M. 2014. Analysis and pollution assessment of heavy metal in soil, Perlis. Malaysian J. Anal Sci. 18 (1): $155-161$

Smołka-Danielowska, D. 2006. Heavy metals in fly ash from a coal-fired power station in Poland. Polish J. Env. Stud. 15(6): 943-946.

Sträter, E., Westbeld, A. \& Klemm, O. 2010. Pollution in coastal fog at Alto Patache, Northern Chile. Environ Sci Pollut Res Int. 17(9):1563-73.

Tchounwou P.B., Ishaque, A. \& Schneider, J. 2001. Cytotoxicity and transcriptional activation of stress genes in human liver carcinoma cells (HepG2) exposed to cadmium chloride. Mol Cell Biochem. 222: 21-28.

Tchounwou, P. B., Yedjou, C. G., Patlolla, A. K., \& Sutton, D. J. (2012). Heavy metal toxicity and the environment. In: Luch, A. (Ed.). Molecular, clinical and environmental toxicology (pp. 133-164). Basel, Springer

Tchounwou, P., Newsome, C., Williams, J. \& Glass, K. (2008). Copper-induced cytotoxicity and transcriptional activation of stress genes in human liver carcinoma cells. Metal Ions Biol Med. 10: 285-290.

Tchounwou, P. B., Centeno J. A. \& Patlolla A. K. 2004a. Arsenic toxicity, mutagenesis and carcinogenesis - A health risk assessment and management approach. Mol Cell Biochem. 255: 47-55.

Tchounwou, P.B, Yedjou, C.G., Foxx, D., Ishaque, A. \& Shen, E. 2004b. Leadinduced cytotoxicity andtranscriptional activation of stress genes in human liver carcinoma cells (HepG2). Mol Cell Biochem. 255:161-170.

Thomas, R. 2008. Practical Guide to ICP-MS: A Tutorial for Beginners. (Second Edition). Boca Raton, FL: CRC Press.

Tsai, Y. I. \& Cheng, M. T. 2004. Characterization of chemical species in atmospheric aerosols in a metropolitan basin. Chemosphere 54: 11711181.

Wang, R., Balkanski, Y., Boucher, O., Bopp, L., Chappell, A., Ciais, P., Hauglustaine, D., Peñuelas, A. \& Tao, S. 2015. Sources, transport and deposition of iron in the global atmosphere. Atmos. Chem. Phys. 15: 62476270.

WHO/FAO/IAEA 1996. Trace Elements in Human Nutrition and Health. World Health Organization. Switzerland: Geneva.

Wild, P., Bourgkard, E. \& Paris, C. 2009. Lung Cancer and Exposure to Metals: The Epidemiological Evidence. Meth Mol Biol. 472: 139-167. Doi: 10.1007/978-1-60327-492-0_6.

Yedjou, C.G. \& Tchounwou P.B. 2006. Oxidative stress in human leukemia cells (HL-60), human liver carcinoma cells (HepG2) and human Jerkat-T cells exposed to arsenic trioxide. Metal Ions Biol Med. 9: 298-303.

Yedjou, G. C. \& Tchounwou, P. B. 2007. In vitro cytotoxic and genotoxic effects of arsenic trioxide on human leukemia cells using the MTT and alkaline single cell gel electrophoresis (comet) assays. Mol Cell Biochem. 301: 123-130.

Yedjou, G. C. \& Tchounwou, P. B. 2008. N-acetyl-cysteine affords protection against lead-induced cytotoxicity and oxidative stress in human liver carcinoma (HepG2) cells. Intl J Environ Res Public Health 4(2):132-137. 